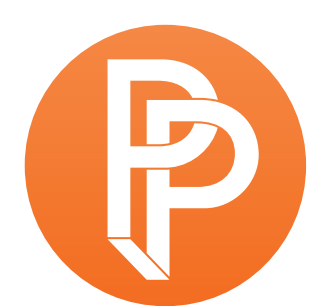

PERFORMANCE

PHILOSOPHY

\title{
THE PLACE OF PLANTS: SPATIALITY, MOVEMENT, GROWTH
}

\section{MICHAEL MARDER IKERBASQUE / UNIVERSITY OF THE BASQUE COUNTRY, VITORIA-GASTEIZ}

Note: A version of this paper was delivered at the opening of the exhibition Plant Science at King's College, London, on May 22, 2013:

\begin{abstract}
The result of a two year collaboration with the Estates Department and the Performance Foundation at King's College London, site-specific performance and installation artists Ewan Forster and Christopher Heighes created an evocative three-room installation in response to the university's abandoned Plant Sciences Department laboratories in Herne Hill. [...] Plant Science is a meditation on the apparatus of study and learning; an exploration of the performative qualities of the lab bench and workstation as sites of intense scrutiny and discovery and devices for pedagogical exchange and experiment. Glasshouse, green-board, test bench, workstation, fume cupboard, propagation bed, specimen cabinet and fire door - a building distilled to its essential elements, clarified, separated and reconstituted in the neoclassical environment of Somerset House. (King's College London 2013)
\end{abstract}

We are in a place. Here, in this place, human beings hoped not only to learn something about plants, but also to learn from them and perhaps even with them. The study of bioenergetics, for instance, focused, in the words of Prof. Bradbeer, on "understanding the light-reaction of plants with the very long-term aim of devising artificial systems for the production of fuel from sunlight and water" (Bradbeer 2005). In other words, the goal was to learn from plants how to perform photosynthesis. 
But what does the expression "to be in a place" signify? The simple account by a scientist already uproots us from the "here" and throws us into the flux of time, with its long-term plans and expectations. Even if we are here, our minds are wandering elsewhere, and the bodies will follow suit soon. It will be up to that other "Plant Science," which names an art installation, to bring us back-back here-, quasi-miraculously giving the place a deeper sense and a second lease on life. The redemptive power of aesthetics does not change the fact that the "here," wherein we find ourselves, is transitory; that, for us, as for all non-sessile animals, it can become something that is "over there" as soon as we abandon the spot where we sit or stand; and that, consequently, it may be destroyed, converted into a "nowhere," without affecting us-who will survive its destructionin the core of our being. And yet, it forces us to put into perspective our relation to a place, which is, by the same token, a relation to the places between which we circulate.

That is how Hegel's Phenomenology of Spirit too begins, as it puts into relief the instability and selfnegation of the "here." In the ever-shifting world of "sense-certainty," every "this" supplanted by another singularity passes into "that," every "now" becomes a "then," and every "here" —an "over there." Just listen to the German master's formulation: "'Here' is, for example, the tree. If I turn 'round, this truth has vanished and is converted into its opposite: 'No tree is here, but a house instead.' 'Here' itself does not vanish; on the contrary, it abides constant in the vanishing of the house, the tree, etc., and is indifferently house or tree" (Hegel 1977, 60-1). And what if a tree were not just something "here" but the center-point of its own world with a distinct orientation toward its environment? What if it actively inhabited and organized its place of growth, which, at the same time, moulded it? In that case, the obliteration of its milieu would signify the end of a plant's world and of its life, for, unless it were transplanted by a human being, it would perish along with its "here." A plant's sense of place, mediated by sensitivity to at least fifteen environmental factors, including light, heat, gravity, moisture, etc., and their interactions, is distinct from that of the human. Before and beneath the heady phenomenology of spirit, lies an uncanny phenomenology of the vegetal.

So, we start right here, in the place of growth from which plants seem to be inseparable. We say that a plant does not move, and are confirmed in this by the Latin etymology that imbues it with the sense of "that which is enchained to a place," "that which is driven into the ground," the planted, plantare (Marder 2013, 56). But why should movement be limited to locomotion? Such a limitation is indeed of a relatively recent mintage. In the Aristotelian universe, "change of place" was but one of four meanings of movement, the other three being growth, decay, and change of state or metamorphosis. Now, plants not only participate in the non-locomotive types of movement but are also, to a great extent, defined by them. The Greek word for "plant" is phuton, "a being that grows," while decay is the underside of all finite growth. Metamorphosis is equally fundamental for vegetal life, as Goethe conveys in his influential botanical monograph, The Metamorphosis of Plants (Goethe 2009). There, different plant organs are theorized as a transformed (thickened, rarified, elongated, or condensed) leaf, the original building block of the plant. Of the three types of plant movement, then, I would like to concentrate on growth because it defines the activity in which plants excel the most. 
In fact, "growing beings" is an apt description of plants, animals, and humans, even if, in addition to physical growth, we are also subject to experiential and perhaps spiritual maturation. The problem is that the movement of growth, especially that of the bodily variety, is largely imperceptible. We take cognizance of it usually when the nails become too long, strands of hair fall before our eyes, tree branches come to rest on top of power-lines, and grass reaches all the way up to our waists. The rhythms of growth, within and outside of us, diverge from those of human consciousness. The result is the asynchrony between our attentive gaze and the movement of plants (as well as the physiology of our bodies). It is this ontological time-lag that renders vegetal life so foreign to the vitality of animals and humans, whilst leaving us with the impression that plants are immobile.

At first glance, it appears that we have run into a dead-end, insofar as the possibility of performances inspired by plant movements are concerned. If to perform is necessarily to bestow a form, then performing growth is tantamount to performing the un-performable. Of course, much of what we know as "culture" and "civilization" depends, whether directly or obliquely, on a channeling of growth into particular directions that should ideally coincide with a consciously devised plan. Without human meddling with the vectors of plant growth, there wouldn't have been English gardens, edible apples, or Trans-Amazonian highways. Even decay-that other vegetal movement-is steered by culture: grapes are fermented in such as a way as to turn into wine; wheat, mixed into dough, is fermented to produce bread, and so on. More often than not, the cultural modes of routing growth rely on violent impositions that fail to respect the inherent tendencies of the plants themselves. The notion of economic growth is oblivious to the limits, within which quantitative increase may unfold. The disastrous footprint humans have left on the Amazon region has resulted from the attempt to tame and harness exuberant vegetal growth through unprecedented deforestation. The loss of plant biodiversity worldwide and the propagation of monocultures contravene the multiplicity and dispersion favored by the plants themselves. An aesthetic attitude to vegetal life is vital as an alternative to such impositions.

\section{Performing Growth}

As I have just mentioned, performing growth is performing the un-performable. Nonetheless, it is possible to devise creative solutions that would diminish, if not overcome altogether, the time-lag between human and plant movements. Time-lapse photography can speed up the vegetal movement of growth to such an extent that its rhythms would match those of the human consciousness. Indeed, some of the earliest experiments in this photographic technique involved plants, and Aristotle's notion of growth as a kind of movement found its empirical substantiation. As a seedling germinates, for example, the elongation of its stem is accompanied by rotation around its own axis (the so-called nutational movement) (Heathcote and Aston 1970, 997-1002). Imperceptible in real time, these movements can be, to some extent, synchronized with the human perception of mobility thanks to a technological mediation that breaks down, parses out, and recomposes the temporality of our experience. The inverse process of our slowing down, on the 
other hand, will produce mixed results, as it will inevitably meet inflexible limits. Much as we wish, we cannot slow down enough to come anywhere close to the speed of vegetal growth.

Still, a filmic alteration of the plant's temporal rhythms, made to coincide with that of human temporality, is not free of the residual violence that takes place whenever alien frames of reference are imposed on a given form of life. If we are to believe Heidegger's thesis that the meaning of being is time, then denying the plant its own time amounts to robbing it of its being. So, how can art follow the movement of growth with the least possible interference, heeding the call "Follow the plants!" which Deleuze and Guattari sound in A Thousand Plateaus $(1987,11)$ ?

Perhaps, instead of controlling the movement of growth, artists could literally join it, especially because, like all living beings, they already are it? For all his fascination with robotics and technology, this is the case with some works by the Australian performance artist, Stelarc. In his infamous piece $A$ Third Ear (2006), Stelarc had a cell-cultivated ear implanted in his arm. Much like a grafted tree limb, the third ear disrupted the organismic symmetry of the other two auditory organs, as much as the functionality of this thing, "ear". It was an organ that broke free from the totalizing logic of an animal organism and, in its superfluity, gestured toward the anarchic growth of plants that proceeds by modular development, multiplying extensions without adding a new vital function. In this piece, then, the artwork was entrusted to the movement of growth, making the human performer more plant- than animal-like.

Even more pertinently, Mathilde Roussel's recent exhibition, Lives of Grass (2010), taught us how art can relinquish the human form to vegetal growth. The display's life-sized, anthropomorphic figures filled with soil served as the substratum for the germination of grass. As grass began to grow, resembling hair, the figures appeared even more human. It is not difficult to guess how the display evolved thereafter. Without outside interference, the grass gradually swallowed up the human shapes it had previously outlined, and leveled down all differentiations (as it always does). For once, humans proved to be literally and conceptually lower than vegetation, which they provided with a material foundation and to which they bowed, accepting the untamable exuberance of plant life.

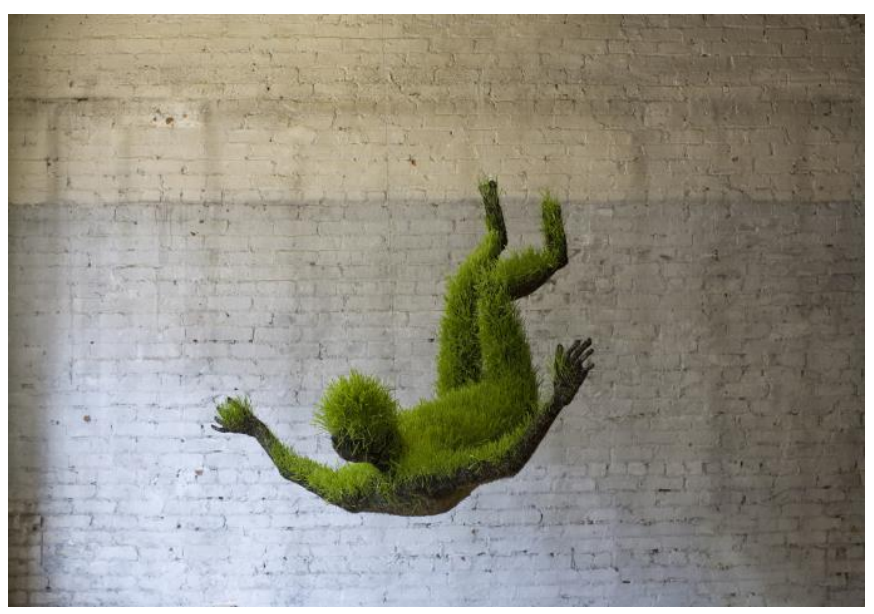

25.08.79 \#1 (2010). Soil, wheat seeds, recycled metal, fabric. (c) Mathilde Roussel. All rights reserved. 


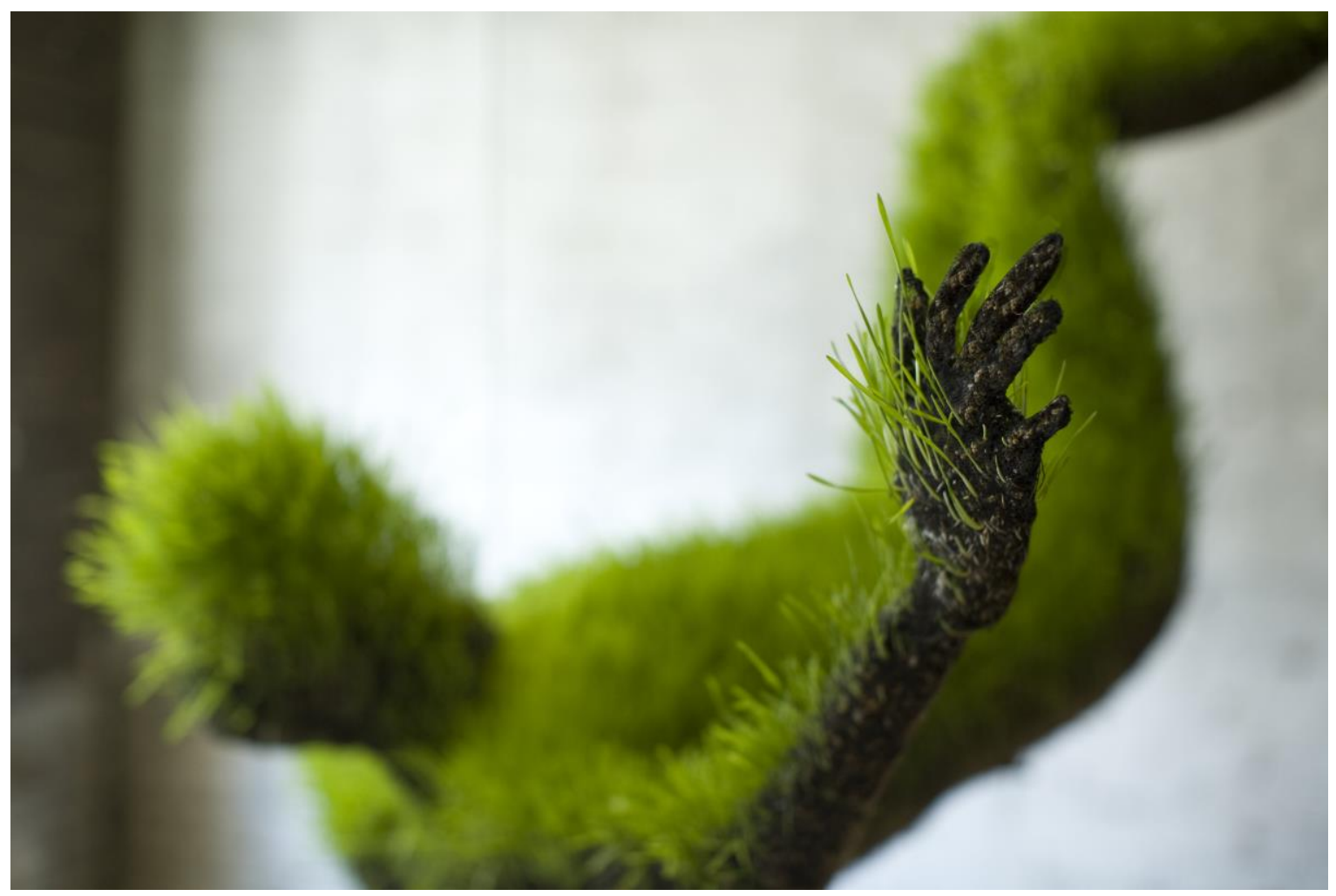

25.08.79 \#1 (2010) (detail). (c) Mathilde Roussel. All rights reserved.

To be sure, some plants do move in ways that are visible to the naked eye. Venus flytrap abruptly closes its lobes if it is stimulated at least twice in a span of twenty seconds. Touch-me-not, or Mimosa pudica, folds its leaves by rapidly pumping water out of the cells in response to tactile stimuli. Both species are able to react in a matter of seconds, thanks to their electrical action potentials (APs), remarkably similar to the firing of our nervous system (Baluška et al. 2005, 10611). Stilt palms, while moving imperceptibly, nevertheless move in the sense of locomotion; by growing new stilt-like roots (hence the name), using them as support structures for the trunk, and abandoning their old roots, they get the chance to forage for light and resources in areas quite distant from the original site of their growth. As Anthony Trevawas, a pioneer of plant intelligence studies from the University of Edinburgh, explains it, the tree changes its site in response to "a spatial map constructed by the shoot" (Trewavas 2004, 353-7). In all these cases, either the timescale of vegetal behaviors or the content of that behavior (movement as locomotion) coincides with human temporality or conduct.

But let us go back to the absolute "here" of the plant. There is nothing more difficult for us than to linger patiently in the "here," without as much as fantasizing about something that lies "over there", where we are not. Heidegger, for his part, understood human existence precisely as the possibility of "being-there" (i.e, not here, despite the literal translation of existence, or Da-sein). By implication, he deemed other living beings, tethered to the immanence of the "here" and to pure present, to be outside the sphere of existence, which hinges on a temporal stretching between the past of 
thrownness and the future of projection (Heidegger 1962). The plant's relation to space-not to mention that of the animal-testifies to the problematic nature of this assumption.

What we urgently need is an elaboration on the vegetal equivalent to the existential spatiality of Dasein; that is to say, a comparative analysis of our construction of, and interaction with, lived space and a parallel construction and interaction in the case of plants. How do plants make sense of the places they inhabit?

The "here," where a seed first falls, is not homogeneous, from the standpoint of the germinating seed itself. After the initial rootlet is established, the movement of growth is bifurcated; it proceeds in two directions at once, stretching up and down simultaneously. Directional gravity sensing in gravitropism allows the plant to discern the difference between what is "up" and what is "down" (Morita 2010, 705-20), introducing the first orientational differentiation into environmental space, imposing a meaningful grid onto it, and transforming it into a place or a habitat. The places occupied by plants are not objectively fixed; they are inhabited, differentiated, and constructed in the course of vegetal life and development.

As the plant continues to grow, it probes and interacts with a greater and greater chunk of its environment, lighting up the space around it with the lived meaning-making activity that emanates from its very growth. That is how environmental space becomes a place of plant life. Much of this exploration entails movement at the edges of plants: the production of new shoots, the unfurling of leafs, and the traveling of sensitive root tips in underground mazes, in a quest for moisture and nutrients. "Spacers" are projected into a habitat in search of optimal feeding sites (Bell 1984, 4865). The contours of a place change in keeping with the dynamism of growth, as the plant extends its reach further both vertically and laterally. If anything, the vegetal sense of space is richer than ours, to the extent that plants conduct, so to speak, a double life, above and below ground-level.

It is worth pointing out, however, that the experience of the world from the standpoint of sessile beings-whether animals or plants-has its own peculiarities, compared to the world sensed from the perspective of mobile organisms. Aside from the stretching of spacers and roots that direct themselves towards whatever they seek, the plant does not come out to meet the world outside the locale where it grows. Instead, the world comes to it: a squirrel climbs a tree branch, a child extends her hand to pluck a flower, and so forth. That is why plants had to develop an elaborate array of biochemical signals, defenses, and adaptations that respond to whatever happens in their vicinity. What seems to be a reactive behavior is a key feature of sessile being-in-the-world.

I have already noted, with reference to the work of Anthony Trewavas, that plants also actively gather information about and construct the equivalent to what we call "the cognitive maps" of their environment (Trewavas 2003). A baroque proliferation of vegetal extensions is meant not only to capture the greatest possible amount of solar energy, but also to get the most multifaceted view of the surroundings imaginable. Modular development, replicating the same plant structures (such as branches and leaves), ensures that each plant has a number of "green antennae" constantly monitoring the environment. What, to us, appears to be a redundancy, is, for the plant, a way to be in touch with, if not to be attentive to, the place of its growth. Plants grow in contiguity with, not 
against, their environmental niches. They have nowhere to run away to or hide, which is why an ongoing assessment of dangers and challenges is all the more indispensable for them. As I put it elsewhere, "[a] rooted mode of being and thinking is characterized by extreme attention to the place and context of growth and, hence, sensitivity that at times exceeds that of animals" (Marder 2012, 4).

Let us not run ahead of ourselves, however. Why not accompany the movement of growth from the beginning, or even before it commences? The initial throw of the seed may be quite random. It is a throw of the dice par excellence, as it is far from certain that the seed would land on the right kind of soil, would have enough moisture to germinate, would be subject to optimal temperatures needed for growth, etc. But we are not the only ones who throw or sow seeds; in doing so, we repeat an operation of the plants themselves. Releasing pollen, for instance, and commending it to the mercy of wind or insects, they throw themselves out without any guarantee of success. That, too, is a mode of plant movement: catching a ride on airflows or on the wings of a honeybee. That is how the plant dreams up its elsewhere-an unknown "over-there," often far from the "here" of its growth-a destination it might never reach. Of course, it throws only a part of itself, the part that is perhaps inessential, while we are thrown into existence in the totality of our being, as Heidegger would retort. Fair enough, but this observation does not invalidate the opening of a vegetal escape route from the straightjacket of sheer immanence. The plant's throw may yield a prototype for all existential thrownness, which could happen absurdly, "for nothing."

While the beginning of growth is oft-times alleatory, there is nothing haphazard about its ongoing patterns. Having received various types of information about the surroundings, the plant deliberately places new leaves and shoots in the most advantageous spots, as Richard Karban relates in his take on plant behavior (Karban 2008, 728). The investment of energy that goes into this endeavor is so high that it can literally be a matter of life and death; especially in environments with little resources, the plant's decision on the exact site of new growth-the decision that arises at the intersection of over fifteen environmental stimuli in plant signal processing-does not leave much margin for error. From our phenomenological vantage point, we might say that the mapping of space and the deliberate placement of new leaves and shoots allow the plant to forge (construct and construe) the place of its growth, meaningful (and, hence, livable) from its unique standpoint and physical position.

We now have a rough idea of what the place of plants (which is also a place for them, interpreted by them) looks like. Even so, we cannot put ourselves in this place, much less perform whatever happens in it, since we cannot put ourselves in the plants' shoes, or, better, their roots. Such a supplanting of the plant would be quite undesirable, since it would only project the human onto another form of life, often deemed to be the other form of life, or even the other of life in its fullest and highest manifestation. Having said that, we can attempt a certain performative approximation to the phenomenology of the plants themselves. This is where the arts can lead the way, broadening the limits of our theoretical imagination and helping us to explore the unique place of plant life. For, isn't attempting the impossible and imagining other worlds the highest vocation of 
art? So, I put this forth as a challenge to those artists and performers who would dare at the very least to include the spatiality, movement, and perspective of the vegetal in their work.

The inclusion of the vegetal in artistic work does not imply a mere representation of plants. This commonsense approach inevitably reduces that which is represented to an object of contemplation, robbing it of its anonymous, a-cephalic, strange subjectivity. As an alternative, we can tease out, aesthetically, the vegetal heritage in us, the permutations of both physical and sublimated growth in human beings, the fleeting sense of our own plant-hood.

Mathilde Roussel has already gestured in this direction in her Echology (2013). Here, parts of the plant world, contained in glass jars, are recoded and re-grafted onto the human body. For instance, a vessel containing tree bark is labeled "SKIN," another containing dry twigs bears the inscription "BONES," while yet another, holding grass, features the word "HAIR." With some variations, these echoes of the plant in the human crop up throughout the history of philosophy. For instance, Hegel considered our skeletal structure to be a trace of the inorganic world, coexisting in a dialectical tension with the flexible animal tissues that surround and conceptually negate it. Apparently inessential, superficial, open-ended in their growth-hair and nails, fur and feathers, were similarly conceived by the German philosopher on the model of vegetal proliferation. As he writes in his lectures on aesthetics: "The real seat of the activities of organic life remains veiled from our vision;

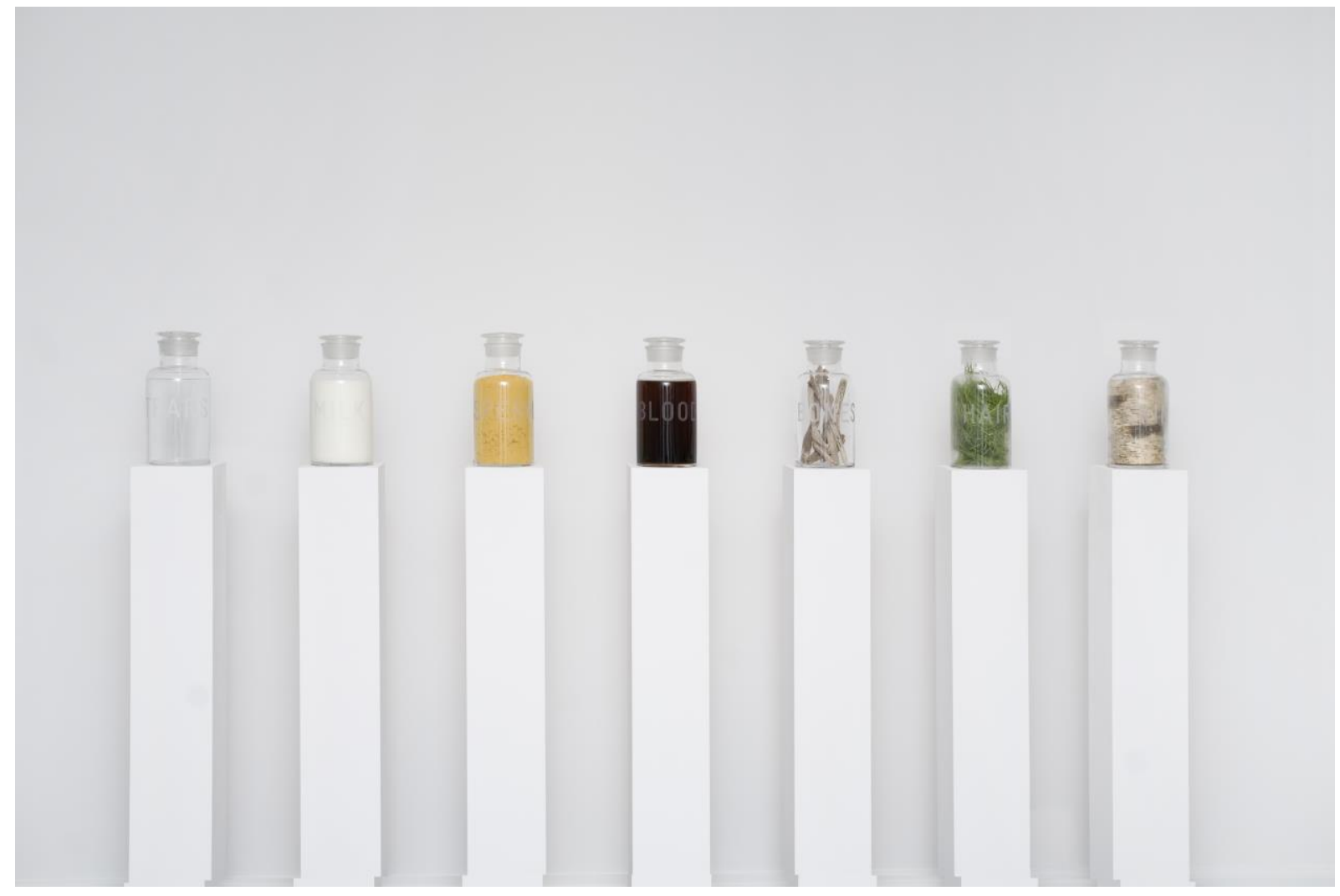


we see only the external outlines of the animal's shape, and this again is covered throughout by feathers, scales, hair, pelt, prickles, or shells. Such covering does belong to the animal kingdom, but in animals it has forms drawn from the kingdom of plants" (Hegel 1998, 145). Such is the semantic matrix, with which Roussel's work is in a constant dialogue.

In addition to engaging with the products of growth, artists can plug their work into the process of growth, broadly understood as a striving. What would it mean for a performance, or for another artistic practice, to strive like a plant in all directions at once, excessively, and with the utmost spatial or corporeal attention paid to every inch of the place where it unfolds? Where is the border between concentration and scattering here? And how can we first throw ourselves into such a performance or creative act, the way a seed is sown without any guarantee that it would germinate? What would need to be set up for this kind of performance to grow, to extend its reach, while remaining rooted in the context wherein it first cropped up? What would its modular selfcomplication or self-replication in this place, which I have provocatively analogized to the Baroque, entail? And how, if at all, would it engage with the plants themselves?

I leave these questions suspended. We have already moved too far beyond this place, the "here" where we are. It is time to come back and to abide in everything that, despite all odds, Plant Science has made possible once again. This time is the time of grace, gifted to us and to this place by art.

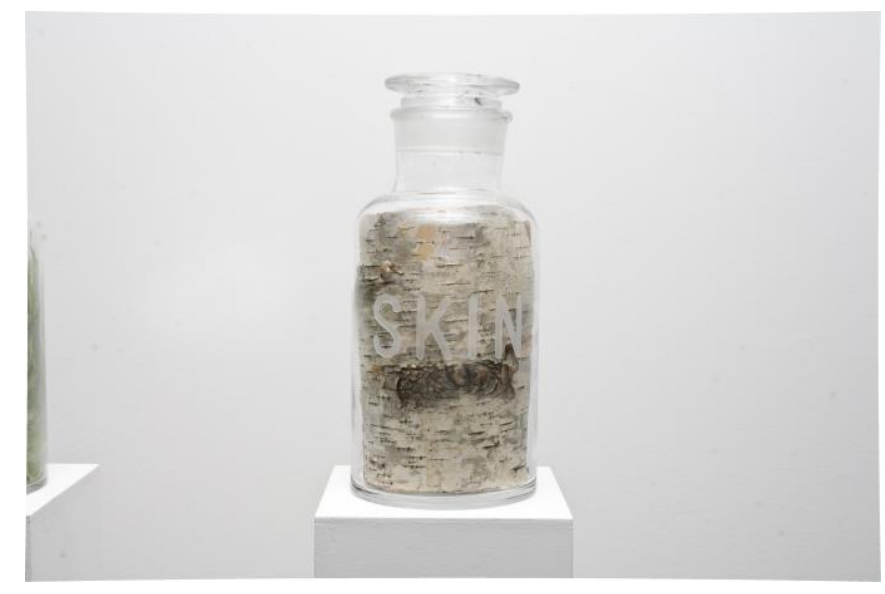

Echology (2012) (detail). @ Mathilde Roussel. All rights reserved. 


\section{Works Cited}

Baluška, Frantisek, Dieter Volkmann, and Diedrik Menzel. 2005. "Plant Synapses: Actin-Based Domains for Cell-toCell Communication." Trends in Plant Science $10 \quad$ (3): 106-11. http://dx.doi.org/10.1016/j.tplants.2005.01.002.

Bell, A.D. 1984. "Dynamic Morphology: A Contribution to Plant Population Ecology." In Perspectives on Plant Population Ecology, edited by Rodolfo Dirzo and José Sarukhán, 48-65. Sunderland: Sinauer.

Bradbeer, J.W. 2005. "Botany in Half Moon Lane." The Dulwich Society Newsletter. Accessed January 7, 2015. http://www. dulwichsociety.com/newsletters/46summer2005/163-botany-in-half-moon-lane.

Deleuze, Gilles and Felix Guattari. 1987. A Thousand Plateaus: Capitalism and Schizophrenia. Translated by Brian Massumi. Minneapolis: University of Minnesota Press.

Goethe, Johann Wolfgang. 2009. The Metamorphosis of Plants. Cambridge MA: MIT Press.

Heathcote, David G., and T. J. Aston. 1970. "The Physiology of Plant Nutation." Journal of Experimental Botany 21 (4): 997-1002. http://dx.doi.org/10.1093/jxb/21.4.997.

Hegel, G. W. F. 1977. Phenomenology of Spirit. Translated by A. V. Miller. Oxford: Oxford University Press. 1998. Aesthetics: Lectures on Fine Art. Translated by T. Knox. Oxford: Oxford University Press.

Heidegger, Martin. 1962. Being and Time. Translated by John Macquarrie and Edward Robinson. New York: Harper \& Row Publishers.

Karban, Richard. 2008. "Plant Behaviour and Communication." Ecology Letters 11 (7): 727-39. http://dx.doi.org/10.1111/j.1461-0248.2008.01183.x.

King's College London. 2013. "Plant Science". Accessed January 7, 2015. http://www.kcl.ac.uk/cultural/ culturalinstitute/showcase/past/pp/1213/exhibitions/plantscience.aspx.

Marder, Michael. 2012. "Plant Intentionality and the Phenomenological Framework of Plant Intelligence." Plant Signaling \& Behavior 7 (11): 1365-72. http://dx.doi.org/10.4161/psb.21954.

2013. Plant-Thinking: A Philosophy of Vegetal Life. New York: Columbia University Press.

Morita, Miyo Terao. 2010. "Directional Gravity Sensing in Gravitropism." Annual Review of Plant Biology 61: 705-20. http://dx.doi.org/10.1146/annurev.arplant.043008.092042.

Trewavas, Anthony. 2003. "Aspects of Plant Intelligence." Annals of Botany 92 (1): 1-20. http://dx.doi.org/10.1093/aob/mcg101.

2004. "Aspects of Plant Intelligence: An Answer to Firn." Annals of Botany 93 (4): 353-57. http://dx.doi.org/10.1093/aob/mch059.

\section{Biography}

Michael Marder (michaelmarder.org) is IKERBASQUE Research Professor at the University of the Basque Country, Vitoria-Gasteiz, Spain. His most recent books include The Philosopher's Plant: An Intellectual Herbarium and Pyropolitics: When the World Is Ablaze.

(c) 2015 Michael Marder

(c) (†) Except where otherwise noted, this work is licensed under a Creative Commons Attribution-

EY No SA NonCommercial-ShareAlike 4.0 International License. 